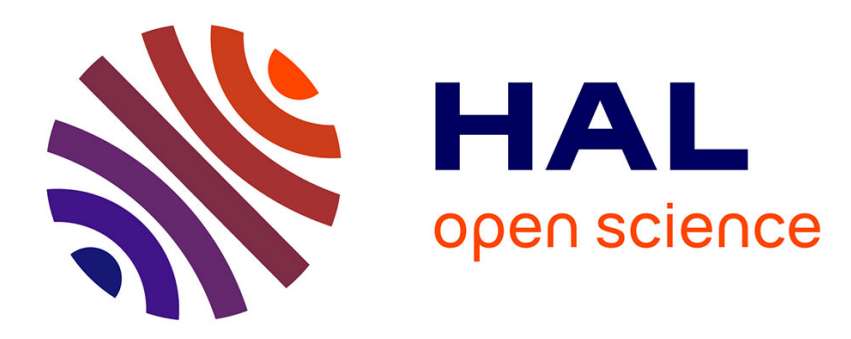

\title{
Organised crime threat assessments: a critical review
}

Andries Johannes Zoutendijk

\section{To cite this version:}

Andries Johannes Zoutendijk. Organised crime threat assessments: a critical review. Crime, Law and Social Change, 2010, 54 (1), pp.63-86. 10.1007/s10611-010-9244-7 . hal-00604882

\section{HAL Id: hal-00604882 \\ https://hal.science/hal-00604882}

Submitted on 30 Jun 2011

HAL is a multi-disciplinary open access archive for the deposit and dissemination of scientific research documents, whether they are published or not. The documents may come from teaching and research institutions in France or abroad, or from public or private research centers.
L'archive ouverte pluridisciplinaire HAL, est destinée au dépôt et à la diffusion de documents scientifiques de niveau recherche, publiés ou non, émanant des établissements d'enseignement et de recherche français ou étrangers, des laboratoires publics ou privés. 


\title{
Organised crime threat assessments: a critical review
}

\author{
Andries Johannes Zoutendijk
}

Published online: 30 June 2010

(C) Springer Science+Business Media B.V. 2010

\begin{abstract}
Since the beginning of the 21st century, several national and international government agencies have initiated organised crime threat assessments. Additionally, a few scholars have published methods to assess the risks and threats of organised crime. These governmental bodies and scholars claim that their reports and methods can demonstrate that certain forms of organised crime are more threatening than others and thus help policy-makers set strategic priorities. In this article I discuss these claims by examining the reliability and validity of the operational definitions of the key concepts used, such as organised crime, threat and risk. This examination reveals that most reports and methods provide insufficient detail-and sometimes even no details at all - to guarantee the reliability and validity of their operational definitions. The search for validity is made particularly difficult by the ambiguity surrounding the concepts of organised crime, threat and risk, while the concept of cost is less problematic. Moreover, establishing what constitutes a threat is at its core a normative decision that cannot be left to intelligence analysts or scientists alone. The challenge ahead lies in acknowledging the normative framework of organised crime threat assessments and within that framework maximising the reliability and validity of the operational definitions of key concepts and related measuring instruments.
\end{abstract}

\section{Introduction}

Since the beginning of the present century an increasing number of domestic and international law enforcement agencies have begun producing so-called Organised Crime Threat Assessments (OCTAs). Currently, these 'future-oriented' ([20]: 13) reports are regularly published by the Belgian Criminal Policy Service ${ }^{1}$ [7], the

\footnotetext{
${ }^{1}$ The Criminal Policy Service (Dienst voor het Strafrechtelijk Beleid - DSB) is an advisory body which is part of the Belgian Federal Ministry of Justice. Although the DSB is in charge of publishing the report, the report is mainly written by the Belgian Federal Police.
}

A. J. Zoutendijk ( $\square)$

Katholieke Universiteit Leuven, Leuven, Belgium

e-mail: Andries.Zoutendijk@law.kuleuven.be 
Criminal Intelligence Service Canada [6], the Dutch National Police Intelligence Service IPOL [20], the Northern Ireland Organised Crime Task Force [26] the UK Serious and Organised Crime Agency [34] as well as Europol [13].

The OCTAs often substitute the so-called organised crime (situation) reports, which many law enforcement agencies had begun publishing in the 1990s and were mainly based on traditional law enforcement data, such as arrest figures and criminal cases. The authors and governmental sponsors of the OCTAs explicitly claim that these reports can provide the readers with new insights about organised crime and its societal consequences. The Belgian DSB ([7]: 3) and the Dutch IPOL ([20]: 13), for example, assert that their OCTAs can demonstrate which forms of organised crime represent a threat for their respective countries-although organised crime is understood as a set of groups by the first agency and as a set of phenomena by the second one. Most OCTAs also have the ambition to provide policy-makers with useful data to set strategic priorities. ${ }^{2}$ Europol, for example, justified the switch from organised crime reports (OCR) to the OCTAs with the following words:

Whereas the OCR was primarily focusing on the description of the organised crime situation in Europe, the OCTA puts an emphasis on the qualitative assessment of this complex and multi-faceted phenomenon. The OCTA, being a forward-looking document, will help decision-makers identify strategic priority areas in the fight against serious and organised crime and to initiate an intelligence process to define operational targets ([12]: 6).

Similar claims are also advanced by the OCTF ([26]: 3) and SOCA ([34]: 3). Some of these reports are influential. In, for example, policy documents of the Belgian Ministries of Internal Affairs and Justice [2,3] and Dutch policy documents frequent reference is made to the respective OCTAs. The Dutch OCTAs, for instance, are sent to the Parliament and are used by the Ministers of Justice and Internal Affairs to justify their policies. SOCA's ([34]: 3) OCTA “is produced to inform UK law enforcement priorities for tackling serious organised crime and other relevant initiatives, such as changes in legislation, regulation or policy". 3 Therefore, we should put these OCTAs through serious study.

The main purpose of this article is to critically review the OCTAs and assess whether their claims are justified. ${ }^{4}$ In addition to the six OCTAs already mentioned, the article also considers three similar forward-looking and evaluative reports on organised crime, which were produced on an ad hoc basis. Two of them are organised crime risk assessments made by the Australian Queensland Crime

\footnotetext{
${ }^{2}$ This form of policy-relevant crime analysis is called strategic analysis: 'Strategic crime analysis is concerned with long-range problems and planning for long-term projects. Strategic analysts examine longterm increases or decreases in crime, known as "crime trends"" ([27]: 7). The alternatives are operational analysis, aiming at producing reports which can be used by criminal investigators on the work floor, and tactical analysis, assisting officers and investigators in identifying and understanding immediate crime problems, happening right now ([21]: 374; [27]: 5-8).

${ }^{3}$ See for instance the Dutch Public Prosecutor's website: http://www.om.nl/actueel/publicaties/land elijk_parket/@143913/brochure_landelijk/ (26-03-2009). See: the Dutch Ministry of Internal Affairs website: http://www.minbzk.nl/115995/nieuw (22-04-2009) and a letter from the Dutch Minister of Justice to the Parliament, available at the website of the Dutch Ministry of Justice www.justitie.nl/images/TK\% 20Brief\%20Nationaal\%20Dreigingsbeeld\%202008_tcm34-147891.pdf

${ }^{4}$ We have limited ourselves to Dutch and English-language reports which were available to us.
} 
Commission and the Queensland Police Service [28] and the QCC's successor agency, the Crime and Misconduct Commission Queensland [5] in 1999 and 2004, respectively. The third one is an assessment of the costs of organised crime carried out by Richard Dubourg and Stephen Prichard [8] on behalf of the UK Home Office in 2007. These reports have similar goals as the OCTAs. The Crime and Misconduct Commission Queensland ([5]: 1), for example, claims it can demonstrate that certain organised crime markets pose a higher risk than others (see also [28]: 1; [8]: 1).

The article also reviews the limited amount of (English and Dutch) scientific literature on this topic. During the last decade, in fact, a few scholars have also demonstrated interest in the development and use of methods to carry out risk and threat assessments of organised crime [1, 22, 24, 32, 36, 37]. In this subset we will also consider the Sleipnir method, developed by the Royal Canadian Mounted Police [31], as it is a method for assessing the threat of organised crime groups, and not an OCTA, unlike the reports of the other governmental agencies. ${ }^{5}$ Most of these authors also claim that their work can help policy-makers set law enforcement priorities ([1]: 272; [24]: 165, 166; [32]: 2; [36]: 472; [37]: 52; see also [31]: 1). For example, Tom Vander Beken's risk-based method aims 'to make an assessment possible which will help policy makers set better priorities and take more suitable (preventive) measures at an earlier stage' ([36]: 472).

Specifically, the article assesses the reliability and validity of the operational definitions developed by the OCTAs and similar institutional and scientific contributions. An operational definition - that is, the definition of a concept in terms of the operations to be carried out when measuring it - is reliable, when it can be reproduced ([4]: 541, 543). 'Good operational definitions are so clearly stated that two independent researchers, following the same operational definition, will measure the same concept or variable in exactly the same way' ([25]: 27). An operational definition is valid 'to the extent that it measures the variable or concept in such a way that it reflects its "true" meaning' (ibid.). It is important to keep in mind that validity and reliability cannot be seen separately. An operational definition can only be valid if it is reliable, but a reliable definition is not necessarily valid. ${ }^{6}$

The first section of this article provides key information on the nine OCTAs and similar reports considered (Table 1). The second section analyses how the authors of the reports have defined their key concepts, organised crime and either threat, cost or risk, and the way they have operationalised these concepts. In such a way we will assess both the reliability and validity of these operational definitions. The third section synthesises the main results of the OCTAs and similar reports. The fourth section reviews the scientific literature on this topic, assessing the reliability and validity of the operational definitions developed by the scholars. The fifth section

\footnotetext{
${ }^{5}$ We realize that strictly speaking the Sleipnir method is not developed by an academic and therefore cannot be considered 'scientific literature'. However, the method is often referred to in scholarly literature and therefore we have chosen to discuss it in this article together with the other scholarly literature.

${ }^{6}$ Suppose, for example, that a criminologist would try to count football hooligans by counting the people attending a football match, who wear a football jersey and shout. This criminologist could probably come up with a reliable operational definition of wearing a football jersey and shouting, which would be consistent enough that it could be used by other researchers in other football stadiums and deliver similar results. However, this operational definition is too broad to identify hooligans. Many people wear football jerseys and shout during a match, but not all of them are hooligans and vice versa.
} 


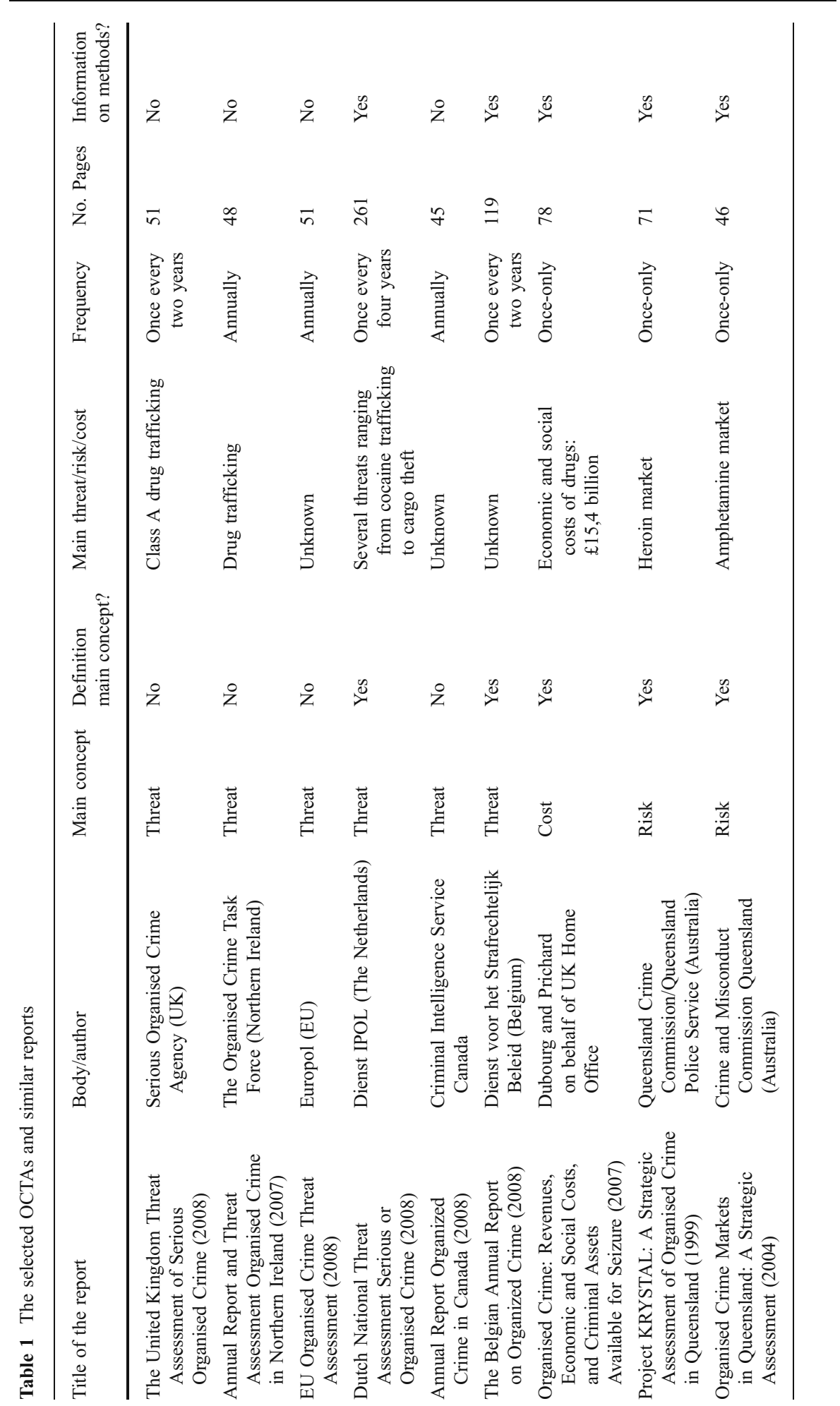


presents a few recommendations for an alternative approach. General conclusions will follow.

\section{Comparing the OCTAs and similar reports}

Analysing organised crime situation reports and threat assessments can be a difficult exercise. Some agencies, such as the CISC [6] and SOCA [34] publish only shorter or adapted versions of their (full) organised crime reports and do not provide any information about their methodology. Even when the full reports are made available, the data, operational definitions and the research methods used remain often hidden from the general public (see also [23]: 98, 99). Despite these limitations, it is nevertheless interesting to compare the nine reports selected across a few basic properties (Table 1).

The frequency with which the reports are published differs. Three of the reports under scrutiny, namely the two Australian reports Project KRYSTAL: A Strategic Assessment of Organised Crime in Queensland [28] and 'Organised Crime Markets in Queensland: A Strategic Assessment' [5] and the report Organised Crime: Revenues, Economic and Social Costs, and Criminal Assets Available for Seizure, written by Dubourg and Prichard [8] on behalf of the UK Home Office are once-only exercises. The two Australian risk assessments will be treated together, because their approach to organised crime markets is similar. The Dutch National Threat Assessment Serious or Organised Crime [20] is published once every four years, the United Kingdom Threat Assessment of Serious Organised Crime [34] and the Belgian Report on Organised Crime [7] once every two years. Three reports are published yearly: the Annual Report Organized Crime in Canada [6], the Annual Report and Threat Assessment Organised Crime in Northern Ireland [26] and the EU Organised Crime Threat Assessment [13].

The size of the published reports differs widely, varying from 45 [6] to 261 [20] pages. As a rule, the longer the report is, the more information it contains. Some of the reports discussed in this article are merely abstracts to inform the general public or the media, such as the public version of the UK OCTA [34], while other contributions, such as the Dutch OCTA [20], seem to have a different audience in mind, such as policymakers, police employees or academics.

Out of the nine reports analysed, four-namely the OCTAs produced by the CISC [6], OCTF [26], SOCA [34], and Europol [13] — hardly provide any details on their data gathering method or method of analysis. Europol, for example, merely states the following about the methodology of its OCTA: 'The OCTA is based on a multisource approach, including law enforcement and non-law enforcement contributions. These include various European agencies as well as the private sector' ([13]: 9). This lack of information on the methods used in the Europol OCTAs is criticised by others as well (e.g. [9, 10]).

The five remaining reports that do clarify their data collection methods-namely the Belgian and Dutch OCTAs [7, 20], the two Australian risk assessments [5, 28] and Dubourg and Prichard's cost assessment [8] — all use literature review and expert interviews as data collection methods. In addition, four of them rely on law enforcement data in various forms, such as criminal proceedings, intelligence reports, and other police documents [5, 7, 20, 28]. 
The reliability of some of the data, such as the intelligence reports, is difficult if not impossible to determine. Moreover, law enforcement data always suffer from problems well-known to criminologists, such as the dark figure [4]. In the case of organised crime, the dark figure is of special concern, because many forms of organised crime, such as drug trafficking-are so-called victimless or consensual crimes. Such crimes are even more underreported than other crimes.

\section{Assessing the reliability and validity of the definition of key concepts}

To assess the reliability and validity of the operational definitions used in the OCTAs, we consider 1) if the key concepts (organised crime, threat, cost or risk) are clearly defined, 2) if these definitions are clearly and consistently translated into empirical observables, that is how they are operationalised, and 3) if these operational definitions measure what they are intended to measure.

\section{Organised crime}

Defining organised crime is challenging, because there is no consensus on its definition. The confusion surrounding the definition of organised crime can be observed in academic as well as in political and law enforcement discourse (e.g. [14, $15,18,38]) .{ }^{7}$ The authors of the OCTAs have envisaged different strategies to come to terms with the nebulosity of the concept. However, most of them do not meet the requirements of reliability and validity, making it difficult to compare the results with the findings from different OCTAs.

Two law enforcement agencies - Europol [13] and the OCTF [26] — do not provide a definition of organised crime in their reports. The other agencies approach organised crime in different ways. The CISC ([6]: 12), DSB ([7]: 5) and SOCA ([34]: 3) define organised crime as groups. The CMCQ ([5]: 7) defines it as activities. Dubourg and Prichard's ([8]: 4) and the QCC's ([28]: 9) definition encompass both organised crime activities and groups, while IPOL ([20]: 15) considers organised crime as phenomena.

In addition to these inconsistencies, most definitions given are broad and vague and hence not properly operationalised. The IPOL report, for example, defines organised crime as follows: 'Criminal phenomena that come into existence by 1) the structural cooperation between persons and 2) are committed for financial or material gain' ([20]: 15; my translation). The imprecision of this definition lies in the fact that many criminal phenomena would fall under it. 'Structural cooperation', for instance, can be interpreted in different ways. Two persons committing several burglaries as well as shoplifting could be labelled as organised crime. The addition 'financial or material gain' only excludes crimes of passion, lust, ideology or revenge.

Similarly, all other definitions of organised crime suffer from lack of clarity and are open to a wide variety of interpretations. ${ }^{8}$ This ambiguity may be useful for

\footnotetext{
${ }^{7}$ An overview of several organised crime definitions can be found here: http://www.organized-crime.de/ OCDEF1.htm (19-05-2009).

${ }^{8}$ Ambiguous words are used in all the reports' organised crime definitions, such as 'considerable importance' or 'considerable period of time' ([7]: 5), 'substantial planning' ([5]: 7), etc.
} 
political purposes, but it makes the operationalisation of these definitions less reliable and less valid. It is, for example, not always clear on what grounds some organised crime activities or phenomena are included in the reports and others are not. IPOL ([20]: 16), for example, bases its list of organised crime phenomena on the outcome of a working group that involved representatives of the National Public Prosecutor, the Prosecutor General, the Ministries of Home Affairs and Justice and IPOL itself. A different working group might come up with a different list of phenomena.

The (validity) question is: are we measuring organised crime and not something else? Since there is no consensus on the definition of organised crime, this question is difficult to answer. A radical solution to this problem could be to accept the fact that organised crime is a political construct and can only be studied if the researcher is willing to embrace the official definition of the concept, as suggested by Van Dijck [11]. In such a way, the official definition of organised crime - whatever it is - would be considered valid a priori. However, this step implies acceptance of the fact that different countries may have different - and sometimes contrasting - definitions of organised crime and that the OCTAs cannot be compared with each other.

\section{Threat}

Two-third of the reports reviewed (six out of nine) aim to assess the threat of organised crime (Table 1). This means that either the title of the report contains the word 'threat', or that a threat assessment is carried out in the report. The Canadian, Northern Ireland and UK OCTAs [6, 26, 34] contain neither a definition nor an operationalisation of the word 'threat'. ${ }^{9}$ Europol's 2008 OCTA does not contain a definition of threat either, but does present a list of seven indicators or attributes ${ }^{10}$ which, according to Europol, would make statements on the threat of organised crime groups possible. However, the report does not explain how these indicators are operationalised and why these indicators were chosen in the first place. Because these four reports provide no definitions of threat, it is impossible to assess the reliability or the validity of such definitions.

The remaining two OCTAs [7, 20] do put forward a definition of threat. However, this does not rule out all doubts. In their 261-pages 2008 report, IPOL defines threat in the following way:

As a threat will be considered those criminal activities, for which there are proven indications that they will manifest themselves in the coming years in the form of a more than a once-only cooperation of two or more persons that together aim to make profits, that multiple crime groups are involved in those criminal activities and that in their totality those activities will have serious consequences for the Dutch society ([20]: 23, my translation).

The seriousness of the consequences is assessed by looking at 'the expected frequency of the criminal activity, the kind of consequences and the ease with which the possible harm could be limited (controllability)' (ibid.). The kind of consequences is

\footnotetext{
${ }^{9}$ A definition of threat may be provided by the longer and confidential versions of the CISC and SOCA reports but these are not available for public scrutiny.

${ }^{10}$ Europol's ([13]: 13) indicators are: international dimension, group structures, use of legitimate business structures, specialization, influence, use of violence, and counter measures.
} 
divided into two main categories, direct harms (e.g. physical damage, property damage) and indirect harms (e.g. prevention costs, damage to interests).

These definitions leave the reader with a few questions, particularly regarding the criteria put forward to identify an organised crime activity as a threat. Multiple crime groups must be involved in order for an activity to constitute a threat. How many groups are to be involved? How many times does the activity have to be carried out? And which consequences are serious enough to label an activity as a threat? IPOL does not answer the first two questions in its report and comes up with a relativistic answer to the last one: 'There are no objective measures to determine the seriousness of the consequences of a criminal activity. The judgement on the qualification is based on intersubjectivity' ([20]: 25 , my translation). ${ }^{11}$

This is an honest and crucial remark. IPOL admits that it is impossible to objectively determine the seriousness of the consequences of criminal activities. From this, it logically follows that it is impossible to come up with an objective list of threats. In other words, the list of threats presented by IPOL is in essence arbitrary, because it represents what IPOL perceives as threatening. It is likely that a different group of people — whether they be police analysts, academic researchers or ordinary citizens - could come up with a different set of serious consequences of organised crime and, consequently, with a different list of organised crime threats.

A different interpretation of the concept of threat can be found in the Belgian OCTA. While IPOL considers the threat level of criminal phenomena, the DSB focuses on criminal organisations:

To meet the conditions of a threat analysis of organised crime, it must be determined what makes a criminal organisation threatening. A "good" criminal organisation should be distinguished from a "bad" one, by using prudent criteria. We have limited ourselves to two dimensions which, in our opinion, most accurately reflect this threat: efficiency and durability. Organisation A poses a larger threat than organisation B if it is efficient in developing its (il)legal activities, but also turns out to have a longer durability ([7]: 13, my translation).

In a second step, the DSB translates these two dimensions, efficiency and durability of the criminal group, into three variables each: the expertise, the dynamic of the group and the reached performance for efficiency, and social cohesion, developed counterstrategies and the flexibility or adaptive capacity in the case of durability ([7]: 13-16). These six variables are further broken down into more variables, some of which are still quite complicated (e.g. collective consciousness, organisational structure, knowhow, information position, etc.). In trying to operationalise the variables, the DSB provides explanations, which are sometimes difficult to understand, such as 'Thus, the dynamic is linked to the decisive structure within the group and the rules that influence the link between the different elements' ([7]: 14, my translation). ${ }^{12}$ Despite these operationalising efforts, no measurable components can be found in the DSB

\footnotetext{
${ }^{11}$ The seriousness of the consequences of certain organised crime phenomena was established through the so-called Delphi-method: a group of six individuals sat together and discussed whether or not the consequences of a criminal phenomenon are serious enough to call it a threat ([20]: 25). The backgrounds of these individuals and their expertise cannot be ascertained from the report. It seems inevitable that if the group members would be replaced by others the outcome of the Delphi-method will be different.

12 This is a literal translation of the Dutch text.
} 
report. Therefore, the reader cannot trace back on what grounds certain groups are labelled as a threat and others are not. Nor does the DSB explain why these variables would accurately reflect the threat of organised crime groups. If efficient crime groups make, for instance, fewer lethal casualties than inefficient ones, we could even argue the opposite. Moreover, like IPOL, the DSB admits that this list of variables is based on the opinion of the researchers ([7]: 13).

Admittedly, the definition of threat put forward by the Belgian DSB is still work in progress. Despite this caveat, a fundamental question remains if the threat of organised crime can be thoroughly assessed by focusing exclusively on criminal groups and their characteristics (efficiency and durability) rather than on the criminal activities they engage in (use of violence/corruption, number of crimes, nature of crimes, etc.). We will return to this question in the final conclusions.

\section{Risk and cost}

Risk is the main concept of two reports produced by two crime commissions of the Australian state of Queensland ([5, 28]), which assessed local illegal markets (and activities, one should add) in 1999 and 2004: the markets for amphetamine, ecstasy, cocaine, heroin, cannabis, $\mathrm{GHB}^{13}$ and prescription drugs as well as fraud, identity crime, money laundering, property crime, motor vehicle rebirthing, and firearms. The two commissions work with similar conceptions of risk. According to the 1999 report, 'risk is determined by considering the intensity of the threat, how likely it is to occur, and the seriousness of the consequences, should it occur. Integral to this process is the identification of all those at risk and all sources of such risk' ([28]: 30). In the 2004 report, 'risk is a function of the threat of an activity occurring and the harmful consequences of that activity. Risk is commonly given a rating that is expressed in qualitative ${ }^{14}$ terms from low to very high' ([5]: 6). Several words, such as intensity, threat, seriousness and harmful consequences require additional explanation, but the reports provide only limited details.

The two Queensland commissions consider threat as a subdivision of risk and offer the following formulae. Threat is defined as intent and capability, intent is desire and confidence, and capability is resources and knowledge. Desire is subdivided into motives and wishes (ibid.). Clearly, the two commissions interpret threat in a different way than the Belgian and Dutch agencies: 'Threat is effectively a measure of how likely it is that a person or group will succeed in carrying out some activity that may cause harm; and the likelihood of success depends on their intent and capability' ([5]: 6). The Australian definition focuses on groups as the Belgian DSB does. However, the two Queensland commissions also consider the activities carried out by these groups and make probability estimations to determine their threat level.

The measurement of the intent of criminal groups 'relies on the analyst's judgement' and is therefore rather subjective (ibid.). How intent is operationalised cannot be found in the report. The question is what the analyst is supposed to judge when judging a group's intent. The group's capability is assessed by looking at 'the

\footnotetext{
${ }_{13}$ Gamma-Hydroxybutyric Acid: a drug used mostly in the club and party scene.

14 The authors of the report do not explain what they mean by 'qualitative'. If I understand them correctly, they mean it as opposed to quantitative. Risk is not expressed in exact figures, but in discretionary categories ranging from 'low' to 'very high'.
} 
number and mix of people with the relevant skills and knowledge, and access to the prerequisites for a particular type of criminal activity' (ibid.). Though this explanation gives us a clue on how to assess the capability of a group, it lacks detail. What should we do, for example, if we want to compare the capability of one group with that of another? Should we consider 'skills' to be more important or relevant than 'knowledge' or would this not be correct? This is not explained in the Australian reports. Given their original focus on illegal markets, it is also surprising that the two Queensland commissions end up using a definition of threat that is entirely group-oriented. The two commissions do not provide any clear explanation for this choice nor do they explain how the threat posed by specific criminal groups is used to establish whether an illegal market poses a low or high risk.

The study carried out by Dubourg and Prichard on behalf of the Home Office [8] is the only one in our selection that attempts to calculate the (economic and social) costs of organised crime activities. ${ }^{15}$ It singles out three different types of costs:

Costs in anticipation of crime include defensive expenditure (for example, on Chip and Pin to help prevent credit card fraud) and precautionary behaviour and are considered to be a cost of crime since they are based on the risk of becoming a victim.

Costs as a consequence of crime include the value of property stolen or damaged (for example, the value of plastic fraud), time costs of replacing property, documents and so on, the emotional and physical impact and reduced quality of life for victims, and reduced effectiveness at work for people affected by crime. In cases where crime involves violence to the victim, health costs fall on the NHS and other health service providers.

Costs in response to crime are numerous and relate generally to the criminal justice system. This includes costs to police, the Crown Prosecution Service, Magistrates and Crown Courts, legal aid and non legally-aided defence costs, and costs to the prison and probation services ([8]: 2).

Dubourg and Prichard express all economic and social costs 'in monetary terms even if the underlying drivers are not themselves financial' (ibid.). They justify their choice in the following way: 'Market size estimates provide some evidence of the likely resilience of organised crime markets to disruption activities, and, supplemented with further information concerning spending and saving habits, can give some indication of the value of assets available for recovery. Estimates of the social and economic cost provide an indication of the likely benefits to society of reducing organised crime activity, and can thus, at a high level, assist resource prioritisation' (ibid.: ii).

Is this tripartite classification of the costs of organised crime valid? In other words, do these three classifications represent the costs of crime? Already at first sight, it does not seem to be the case. Only the second category, namely the costs as a consequence of crime, are direct costs of (organised) crime. The costs in anticipation of crime as well as the costs in response to crime are not the result or consequence of the crime itself, but of policy decisions, law enforcement priorities

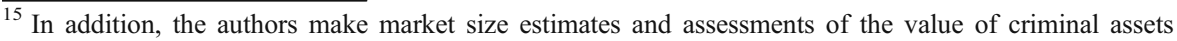
available for seizure.
} 
and public concern with specific crimes or types of crime. It could, for example, very well be that governments or citizens take unnecessary and costly precautions because a crime is feared, but does not present actual risks. Such costs should be regarded as the costs of the fear of crime rather than costs of crime actually taking place. We can apply a similar reasoning to the third category, costs in response to crime. This category leads to a circular reasoning. The highest costs are ascribed to those criminal activities that received the highest priority (highest anticipatory and responsive costs) the previous year. This outcome is likely to further increase attention from policymakers and law enforcement agencies, which leads to an increase in resource allocation to this criminal activity, which leads to an even larger increase of costs, which further increases law enforcement attention, etc., etc. What Dubourg and Prichard are actually measuring is not the costs of organised crime activities alone, but also the amount of money politicians are willing to spend on certain crime problems and the costs resulting from public fear of crime. The Dubourg and Prichard's measurement of 'costs of organised crime' is invalid, because they are not measuring what they intend to measure.

Even if we restrict ourselves to the costs as a consequence of crime, the actual measurement can be difficult. Problems arise when we try to calculate the costs of so-called imponderabilia, things or conditions on which we cannot put a price tag, such as 'emotional impact' and 'reduced quality of life'. Moreover, for some costs the availability of reliable data is limited or non-existent. Dubourg and Prichard are aware of these limitations: 'Due to limited data, many of the valuations are unavoidably very approximate, and subject to large margins of error - strong caveats apply' ([8]: ii). These limitations will become even more apparent when we discuss the results of this and the other selected reports.

\section{Reviewing the main findings of the OCTAs and similar reports}

Even though the operationalisation of most of the key concepts leaves much to be desired, let us now consider which activities or aspects of organised crime are identified as the most serious, threatening or costly and why. As shown in the previous section, there is no consensus on the unit of analysis among the authors of the OCTAs and similar reports. Some of them, such as that of the Belgian DSB [7], focus upon groups. Other ones, such as the IPOL OCTA [20] and the report by Dubourg and Prichard [8] on behalf of the UK Home Office concentrate on criminal activities, still other ones - for example the two Australian reports [5, 28]-focus on markets. This dissension implies that many different things are thought to contribute to the threat level of a group or activity, ranging from negative societal consequences of an activity to the efficiency and durability of a criminal group.

Four reports of our sample, namely the DSB [7], CISC [6], SOCA [34] and Europol [13], contain no systematic list of the threats or risks of organised crime, although some of them pinpoint specific activities as particularly threatening. ${ }^{16}$ For

\footnotetext{
${ }^{16}$ Often the content of these reports is limited to general (and unclear) statements such as: "The OC environment in the EU is evolving and dynamic. Some non-EU-based groups seem to be displaying characteristics of intermediary situations while others remain relatively purely non-EU-based" ([13]: 18).
} 
example, SOCA ([34]: 5) concludes that 'drug trafficking, especially Class A drugs, poses the single greatest threat to the UK'. Other reports reach more structured conclusions. The IPOL [20] and OCTF [26] reports provide a list of threats, the two Australian reports [5, 28] list risks and the Dubourg and Prichard study [8] contains a list of organised crime costs (Table 2).

The contents of these lists vary. IPOL ([20]: 260, 261), for instance, identifies 17 different organised crime threats, ranging from the abuse of legitimate businesses to cargo theft. The Northern Ireland OCTF ([26]: 25) singles out 11, ranging from paramilitary involvement in organised crime to armed robbery. Despite the differences in length, the lists of the Dutch [20] and Northern Irish [26] agencies are partially overlapping: drugs, fraud, robberies and immigration crime are considered threats in both reports. However, there are differences as well. For example, the Northern Irish report considers extortion a threat, while the Dutch report does not. ${ }^{17}$

In all five reports that do provide an explicit list of threats, risks or costs, drug trafficking or the trafficking of a specific type of drug is regarded as posing a threat, risk or (high) cost to society. IPOL, for example, labels cocaine trafficking as a threat, because:

The consequences of trafficking cocaine are serious: the direct consequences such as addiction problems as well as the indirect consequences which are brought about by the illegal character of the cocaine market (money laundering, corruption, intertwinements of legal and illegal sphere). Additionally, the Netherlands' role as a transit country in Europe is reason for concern. [...] The size of the problem, the seriousness of the consequences and the expectation that these will not change in the coming four years, make cocaine trafficking a threat ([20]: 37).

In its turn, the Northern Ireland OCTF considers drug trafficking threatening because:

Organised criminal enterprises continue to make substantial amounts of money through the illicit drugs market in Northern Ireland. The availability of illegal drugs creates fear amongst parents and responsible members of our community and causes a variety of social harms to individuals, families and communities. The importation of drugs is dependent on transport routes and, once established, these routes can provide a doorway for a variety of other illegal commodities to enter the country, including counterfeit products and weapons ([26]: 32).

Clearly, the Dutch and Northern Irish agencies put forward different motivations to justify why drug trafficking should be considered a threat. While both agencies mention the consequences of drug abuse, IPOL stresses 'the indirect consequences resulting from the illegal character of the cocaine market' and the OCTF highlights

\footnotetext{
${ }^{17}$ This is remarkable, because in the Netherlands one of the key underworld figures, Willem Holleeder, was recently sentenced to nine years imprisonment because of extortion. The case is widely regarded as one of the most important recent criminal cases in the Netherlands. See: NRC Handelsblad 'Holleeder krijgt ook van hof 9 jaar' (03-07-2009), available at http://www.nrc.nl/nieuwsthema/holleeder/ article2290138.ece/Holleeder_krijgt_ook_van_hof_9_jaar
} 


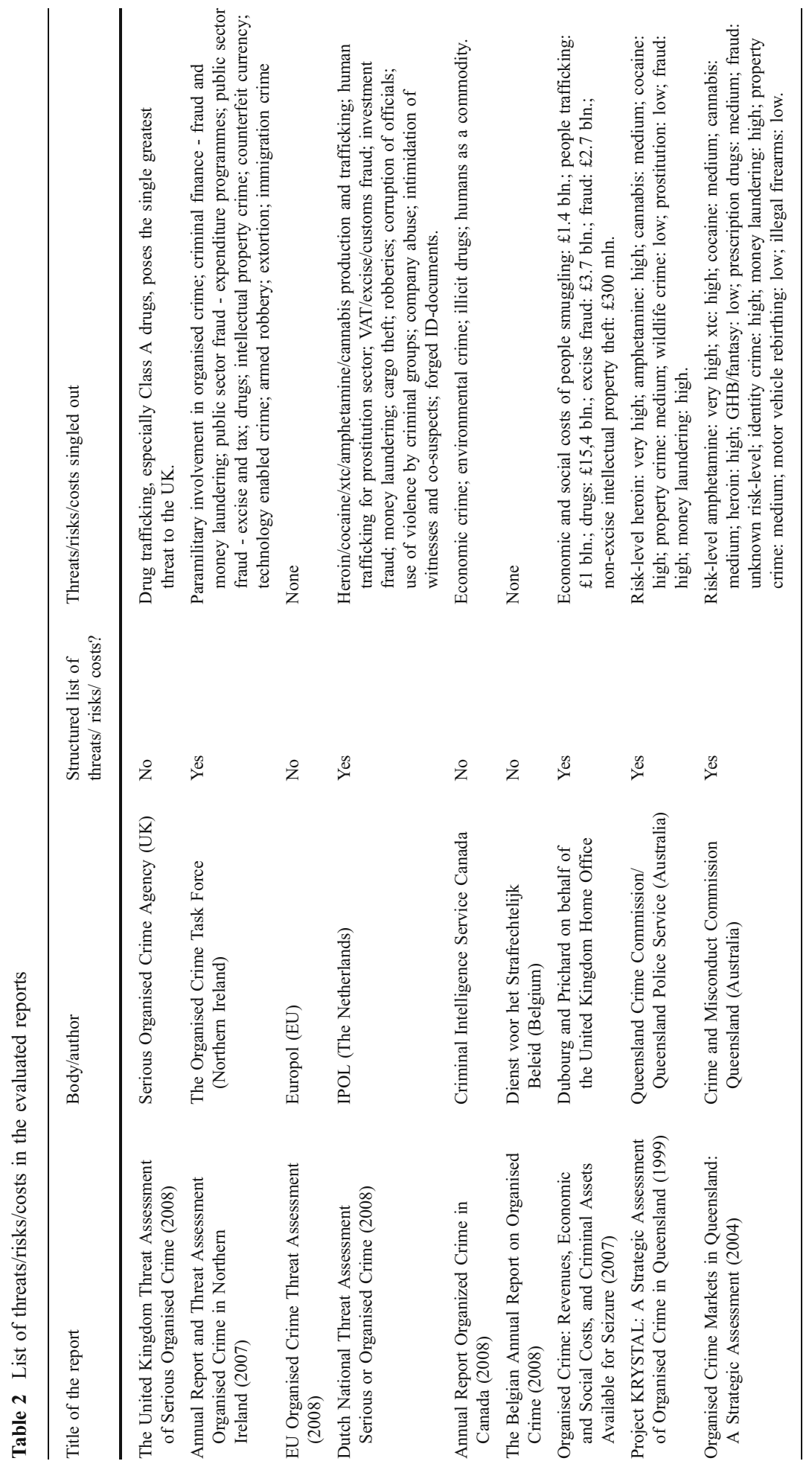


the size of illegal revenues and the fact that drug transport routes can be used for other illegal commodities as well. The question is: who is right? Or is it just a matter of opinion or perception?

The two Australian commissions [5, 28], assessing the risks of organised crime markets, use a four-point scale: low, medium, high and very high risk. Only one market is labelled as a very high risk: in 1999 the heroin market and in 2004 the amphetamine market. As we have explained earlier, the risk assessment formula used by the QCC and CMCQ is as follows: risk = threat and harm; threat = intent and capability; intent $=$ desire and confidence; capability $=$ resources and knowledge. In the 1999 report, resources, knowledge, desire, confidence, intent, capability, threat and harm are all classified as 'very high' in the case of the heroin market. This results in a 'very high' risk of the heroin market ([28]: 36). Why all these variables score very high is not explained in the report. The report does provide statements such as 'The harms, and collateral social costs, associated with the abuse of heroin are far-reaching and diverse' ([28]: 34). However, it is not clear what this means for the risk calculation. Nor is it clear what 'high risk' means, because neither the 1999 nor the 2004 report puts forward clear criteria for its fourpoint risk scale.

The four reports that all consider drug trafficking a threat or (very high) risk have one problem in common: their conclusions cannot be falsified. The Northern Ireland OCTF [26] and the two Australian commissions [5, 28] do not explain on the basis of which criteria some organised crime activities or markets are considered a threat or risk and others are not. IPOL ([20]: 25) does define threat but as it admits itself, determining the seriousness of consequences of a criminal activity is 'a matter of intersubjectivity', that is a normative decision, for which there are no objective criteria.

Focusing on the costs of organised crime, Dubourg and Prichard ([8]: iii) estimate the costs of 'drugs' at a staggering $£ 15,4$ billion ( $€ 15,6$ billion). This estimation is based on two studies [16, 17], whose authors tried to make cost calculations of drug use, using estimates of the amount of users, and healthcare and criminal justice costs per user. However, Dubourg and Prichard's original aim was to assess the costs of organised crime, which is not the same as the costs of drug use. When we speak about organised crime and drugs, we speak about drug trafficking and it is the costs of this activity that need to be assessed and not the costs of drug use. Drug use is not organised crime, nor are drug use-related healthcare problems consequences of organised crime; they are consequences of drug use. Moreover, as mentioned earlier, assessing criminal justice costs to prevent and combat drug trafficking does not give us insight into the costs of the organised crime activity of drug trafficking, as instead lost tax revenues do in the case of VAT-fraud. By assessing criminal justice costs, we get insight into last year's law enforcement and judicial priorities. A cost assessment of organised crime, however, should determine if the costs of a certain organised crime activity are higher (or lower) than those of another activity, irrespective of the law enforcement priority that is given to the activity at the present or in the past.

In spite of these difficulties, Dubourg and Prichard's method has some potential. As mentioned earlier, it avoids the difficulties that come along when trying to operationalise normative concepts such as threat or seriousness. Moreover, monetary figures can be more easily compared, as in the case of the healthcare costs for 
victims or perpetrators, environmental costs, tax losses, etc. However, it is very difficult to come up with even a rough measurement of all costs of organised crime. There are many imponderabilia, such as loss of confidence in the state, declining rule of law, psychological impact, etc., that cannot be translated into hard figures and therefore cannot be measured in this way. Moreover, for many types of costs, there are hardly any reliable data available; sometimes there are no data at all. Governments and scientists using this method should thus focus on those organised crime costs that can be more easily translated into monetary figures and for which some reliable data are available.

\section{Assessing the scientific literature}

In addition to governmental reports, there is a limited amount of scientific literature on how to assess the threats and risks of organised crime (Table 3). ${ }^{18}$ This literature has been primarily developed by Belgian and Dutch authors [22, 24, 36], with some North American contributions as well [1,31]. Despite the predominantly academic origin, this body of work is plagued by the same methodological problems that emerged during the review of the OCTAs and similar reports. The definition of key concepts is often missing. For example, no definition of the key concept of threat is provided by Klerks [22], the RCMP [31] or Albanese [1]. Even when they are present, the operational definitions of key concepts are too unclear to render them reliable (e.g, [24]: 29; [36]: 483) or they rely on an arbitrary choice of indicators so that their validity must be questioned $[1,22,31]$.

The Dutch public administration scientist Jan Kortekaas, for example, tries to identify 'the risks of changes in organised crime that flow from ICT developments' ([24]: 15, my translation). Mirroring the definition of risk of the two Queensland commissions [5, 28], Kortekaas conceptualises risk as 'the combination of the probability that a threat will manifest itself and its unwanted consequences' ([24]: 21). However, he merely defines threat as 'something undesirable' ([24]: 29). Kortekaas proposes a two-step risk analysis: first, threats are identified and in the next step they are assessed or judged. According to him, the threats can be identified by (speaking with) experts or by studying open sources ([24]: 29). The threats can be judged by assessing their probability and identifying their undesirable consequences. Again, the analyst must rely on experts' judgement ([24]: 30). The probability should be judged in terms of 'high' or 'low'; the undesirable consequences in terms of 'serious' or 'not serious.' Kortekaas does not put forward any criteria which could be used to label something as a threat. The only clue he provides us is that a threat needs to be 'something undesirable' ([24]: 29), entrusting the selection entirely to 'experts'. However, he does not explain who those experts are and what their expertise might be.

In a recent attempt to develop a market and product-based model to determine threat levels or risks of organised crime, the U.S. criminologist Jay Albanese ([1]: $263,264)$ places much emphasis on the importance of defining organised crime, but does not properly define either risk or threat, which he ends up using as synonyms.

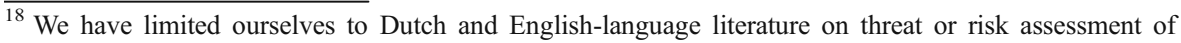
organised crime.
} 
Table 3 Methods to assess organised crime threat and risk

\begin{tabular}{|c|c|c|c|c|}
\hline Title & Author & $\begin{array}{l}\text { Main } \\
\text { concept }\end{array}$ & $\begin{array}{l}\text { Definition } \\
\text { main concept? }\end{array}$ & $\begin{array}{l}\text { How to measure } \\
\text { main concept? }\end{array}$ \\
\hline $\begin{array}{l}\text { Risk Assessment in Organized } \\
\text { Crime: Developing a Market and } \\
\text { Product-based Model to Determine } \\
\text { Threat Levels (article - 2008) }\end{array}$ & Albanese, J. & Risk & No & Attribute list \\
\hline Risky Business (article - 2004) & Vander Beken, $\mathrm{T}$. & Risk & Yes & $\begin{array}{c}\text { Attribute list and } \\
\text { other methods }\end{array}$ \\
\hline $\begin{array}{l}\text { Groot in de Hasj: Theorie en } \\
\text { Praktijk van de Georganiseerde } \\
\text { Criminaliteit (dissertation - 2000) }\end{array}$ & Klerks, P. & Threat & No & Attribute list \\
\hline $\begin{array}{l}\text { Risicoanalyse Georganiseerde } \\
\text { Misdaad. Uitwerking } \\
\text { Instrumentarium en Toepassing } \\
\text { op de ICT-ontwikkelingen } \\
\text { (dissertation - 2005) }\end{array}$ & Kortekaas, J. & Threat & Yes & Interviewing experts \\
\hline $\begin{array}{l}\text { Sleipnir: the Long Matrix for } \\
\text { Organized Crime (law } \\
\text { enforcement document - 2000) }\end{array}$ & $\begin{array}{l}\text { Royal Canadian } \\
\text { Mounted Police }\end{array}$ & Threat & No & Attribute list \\
\hline
\end{tabular}

Specifically, Albanese tries 'to predict incidents of organised crime' in certain illegal markets, however he does not explain what he means by 'incidents of organized crime'. Rather than relying on law enforcement sources, he suggests that 'surveys at the local level could be conducted to determine the circumstances surrounding the supply, demand, regulation, and competition for various illicit products in specific jurisdictions. For example, local citizen, business, police, and perhaps offender surveys could be used to help measure perceptions of supply, demand, regulation, and competition for particular illicit products' ([1]: 271). He translates these four areas (supply, demand, regulation and competition) into ten indicators ${ }^{19}$ which, according to him, would for each illicit market predict the threat level (the number of incidents) of organised crime. Except for the self-evident indicators 'history of organised crime in market' and 'demand for product', it is difficult to see how the other eight indicators - such as objective availability of product or service, elastic/ inelastic nature of demand, profitability, harm ([1]: 270) — could predict the incidents of organised crime in illicit markets. Nor does Albanese explain this.

The methods developed by the Dutch political scientist Peter Klerks [22] and by the Royal Canadian Mounted Police (the so-called Sleipnir method; [31]) have much in common and are both much more scientifically solid than the two first studies reviewed here. The two methods consist of an instrument to assess the threat posed by a criminal group. Although both of them leave the key concept of threat undefined, they do provide a list of attributes - 19 in the case of the RCMP, 28 in the case of Klerks - on which a group can be scored. The higher the score, the more

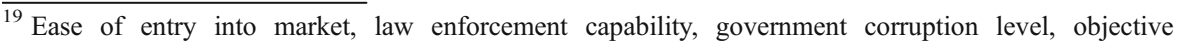
availability of product or service, ease of movement/sale, current demand for product, elastic/inelastic nature of demand, history of organized crime in market, profitability, harm ([1]: 270).
} 
threatening a group is. Some of these attributes overlap, whereas some are different: 'sophistication', 'violence' and geographic scope are mentioned in both studies. On the contrary, the attribute 'monopoly', that is 'control over one or more specific criminal activities within a geographic area of operations, with no tolerance for competition' is mentioned only by the RCMP ([31]: 28) and not by Klerks.

In Klerks' study, the selection of these variables is based on his own opinion and in a footnote Klerks honestly admits that because of this 'an instrument like this can lead to serious differences of opinion' ([22]: 449). Moreover, he assigns different scoring ranges to different variables ([22]: 442-453). For instance, the variable 'place of business' (does the group operate on a local or global level?) has a scoring range from 0 to 26, while the variable 'use of violence' has a range from 0 to 5 ([22]: 442-453). Consequently, the score on the attribute 'place of business' adds significantly more to the final score of the threat level of a criminal group than many other attributes. Apparently, Klerks deems the criminal groups' place of business as adding more to the threat level of a criminal group than its use of violence, but he does not give a justification for his choices. Nor does he provide clear instructions to decide which score a group should receive for each variable. ${ }^{20}$ Because of this insufficient information, Klerks' method remains arbitrary and, if applied, may easily lead to a false sense of objectivity.

In the RCMP project, each attribute receives a score on a four-point scale: high, medium, low and nil (and if no data is available: unknown) ([31]: 17). To each score a rank-ordered value is linked. For instance, a group that scores 'high' on the attribute 'corruption', which stands at the top of the ranking, receives a score of 76; a group that scores 'high' on the attribute 'links to criminal extremist groups', which stands at the bottom of the ranking, receives a score of only 4. In other words, 'corruption' is thought to contribute very much to the threat-level of a group and 'links to criminal extremist groups' very little. If a group scores 'medium' on an attribute, it receives half the score of 'high'. So a group that scores 'medium' on 'corruption' receives a score of 38. If a group scores 'low' on an attribute, it receives half the score of medium and a group receives no score at all in the case an attribute is assessed as 'nil'.

The RCMP used a so-called Delphi-survey amongst Canadian law enforcement officers working on organised crime to identify, define and rank-order the attributes. Through this survey law enforcement officers were asked to give their opinion on the attribute list. This survey was repeated several times until some sort of consensus was reached. The RCMP provides a definition for each attribute and also provides criteria for each score (high, medium, low, nil). However, some of these criteria are open to interpretation. To receive, for example, a 'medium' score on corruption, a group should show 'some ability to infiltrate or corrupt police' ([22]: 23), where 'some ability' is not further determined. The vagueness of such definitions inevitably reduces the reliability of the whole exercise.

Even leaving aside this, the Slepinir method suffers from the limitations typical of the Delphi method (see [33]): as in the case of IPOL's [20] attempt to determine

\footnotetext{
${ }^{20}$ Take for instance the variable 'sophistication', which has a scoring range from 0 to 5 and indicates whether or not a group uses special techniques (e.g. smuggling techniques) ([22]: 442-453). The question is on what grounds a criminal group would receive a score of, for instance, 3 instead of 4 or 5 ? No clear explanation can be found in Klerks' text.
} 
whether or not a criminal phenomenon is a threat, the consensus-based list of attributes is rooted in intersubjectivity. The RCMP's list probably gives a good reflection of the threat that Canadian law enforcement officers believe organised crime groups pose to them and to the Canadian society. However, other Canadian citizens or scientists might have different views on what makes crime groups threatening. Because of this, the RCMP's list of attributes that determine the perceived threat-level of organised crime groups is not valid for the entire Canadian society, but only for (a part of) the Canadian law enforcement. Representatives of other law enforcement agencies, scientists or the general public in Canada or elsewhere might select other attributes or rank them in a different order. For example, the question if corruption makes organised crime groups more threatening than the use of violence is open for debate, as it is basically not a scientific but a normative decision.

As single organised crime groups constitute the unit of analysis of both studies, it is also fair to ask if these methods can fulfil the RCMP's ([31]: 5) claim to constitute a 'strategic intelligence assessment' which can be used to 'inform the deliberations of senior managers setting priorities in our efforts against organized crime'. With few exceptions, organised crime groups in Canada as in most other western developed countries are rather ephemeral and do not last long enough to become the target of long-term law enforcement strategies. Although it is not made explicit, this is probably also a reason why many OCTAs and similar reports reviewed here focus on criminal activities rather than on criminal groups. Which individual groups need to be prioritized by law enforcement seems to be a task of tactical rather than strategic analysis.

In an attempt to help policy makers set priorities, Tom Vander Beken and his Ghent colleagues $[32,36,37]$ put forward the most ambitious method, including an environmental scan, an estimation of criminal networks, which draws on the methods developed by Klerks and RCMP, and an analysis of legal and illegal markets. 'What is required'—writes Vander Beken ([36]: 479) in his most recent article on the topic - is a consideration not just of organized crime groups in isolation, nor of illicit markets in isolation, but an analysis of the interdependencies between these elements and the wider economic spectrum'. While attractive for the broad picture it promises to draw, Vander Beken's risk-based ${ }^{21}$ approach presents some of the difficulties discussed in the previous studies and adds to them new ones, as it does not succeed in providing clear and reproducible - that is reliableinstructions for the tripartite analysis it suggests.

The environmental scan, for example, 'seeks to identify the major relevant trends in the external environment and the overall objectives, or posture, of the agencies involved' ([36]: 487). Vander Beken does not explain which (major relevant) trends he is referring to, nor is it clear what should be understood by 'the external environment'. He states that the environment can be subdivided into four domains: political, economical, social and technological, however this is still very broad. Indeed, a few examples of trends are mentioned (e.g. crime trends, demographics, legislative changes), but Vander Beken does not provide a list. Because of this, almost anything could be meant by, for instance, the social domain ([36]: 489).

\footnotetext{
${ }^{21}$ Vander Beken defines risk as: 'the chance of something — positive and/or negative- happening that will have an impact on objectives' ([36]: 483).
} 
As Klerks [22] and the RCMP [31], Vander Beken too aims to rank criminal groups according to their threat level. His definition of threat is identical to the one used by the Australian CMCQ [5]. The threat level of a group can, according to Vander Beken, be determined by assessing the group's desire, expectations ${ }^{22}$, resources and knowledge. According to him, these four variables can be translated into attributes on which criminal groups can score. The selection of these attributes is based on the lists constructed by Klerks [22] and the RCMP [31]. In this way Vander Beken creates his own list of 21 attributes. ${ }^{23}$ For instance, a criminal group's desire (to engage in illegal activities) can, according to Vander Beken, be assessed by assessing a group's discipline, intelligence gathering, deadly violence, violence, and monopoly ([36]: 494). However, Vander Beken does not further explain these attributes, nor does he translate them into empirical counting units, making it rather difficult to interpret their meaning. He presents the attributes as if they would selfevidently provide an accurate picture of the threat-level of organised crime groups, but he gives no justification for his choices.

To gain a full picture, Vander Beken also suggests making an analysis of legal and illegal markets. According to him, 'the actual levels of organized criminal involvement in illicit markets' ([36]: 495) can be ascertained by looking at 'law enforcement intelligence, prior history of involvement, prosecutions, etc.' as well as 'an appreciation of the dynamics of the markets' ([36]: 499). Vander Beken suggests carrying out this part of the analysis on a macro- as well as micro-level of the market and puts forward several areas (e.g. demographic statistics, the threat of substitute products, business and health) out of which indicators can be extracted which would provide insight into the dynamics of the market in question. ([36]: 502). Why Vander Beken chooses specifically for those areas remains (at least partially) unclear. The indicators on the micro-level supposedly give insight into the functioning of the market ([36]: 497). The reasons behind the choice of the indicators on the macrolevel, however, remain a mystery. Why, for instance, would it be important to extract indicators from the area of 'business and health'? How could these indicators provide better insight into the dynamics of an illegal market? These choices are not grounded properly, giving this part of the method a rather arbitrary character. ${ }^{24}$

\section{An alternative approach}

The objective of most OCTAs is to provide policymakers with information that can be used to set strategic, i.e. long-term priorities. Therefore, we would argue that it makes more sense to regard organised crime as activities instead of criminal groups. As explained earlier, criminal groups are often ephemeral and once busted by the

\footnotetext{
22 The CMCQ ([5]: 6) uses the word confidence instead.

${ }^{23}$ Discipline, intelligence gathering, deadly violence, violence, monopoly, sophistication, risk attitude, accessibility for law enforcement, strategy, insulation, corruption, size of group, working with other groups, local or global, scope, level of finances, mobility, expertise, infiltration, continuity, and multiple enterprises ([36]: 494).

24 This third part of Vander Beken's approach also includes a method to assess the vulnerability of legitimate markets to organised crime, which is not discussed here.
} 
police, usually dissolve. Organised crime activities on the other hand are here to stay and therefore much more useful for strategic priority setting. ${ }^{25}$

Another key objective is to rank these activities. In the studies here reviewed, these rankings are based on the threat-level, riskiness or costliness of organised crime. In other words, these reports try to rank organised crime groups or activities for their 'badness'. The point is that deciding what constitutes a threat and what does not, is a normative decision and opinions cannot be falsified. That corruption is worse or more threatening than the use of violence cannot be falsified. If the RCMP [31] or Klerks [22] develops lists of the most threatening organised crime groups in some geographical areas, these lists cannot be falsified. It is logically impossible to falsify the outcome of their research, because the underlying criteria which are used to determine whether or not a group is threatening are subjective. ${ }^{26}$ One could argue that assessing the threat of organised crime groups with a list of attributes is valid, as long as the researcher explicitly admits that he or she realises that his/her list is just one way of measuring threat. However, in that case, would we not have to conclude that any list of attributes is suitable to measure the threat of organised crime? The meaning of the words 'threats/risks of organised crime' would become hyperreferential (each person has his own interpretation) and therefore meaningless.

The concept of cost seems to be much more neutral and clearer. However, the socalled imponderabilia, such as loss of confidence in the state, declining rule of law, psychological impact, etc. prevent us from calculating all the costs. These costs probably matter to policy makers, but cannot be objectively and accurately measured. Moreover, on many types of costs we have only partial or no data at all, making it impossible to give serious estimations. This method only seems promising if we limit ourselves to measuring things that are easily translatable into monetary figures and on which there is a reasonable amount of reliable data. For example, serious estimations have been made on the profits from drug trafficking (e.g. $[30,35])$. To measure other variables we should try to come up with a less ambitious, but more feasible approach.

In theory it should be possible to rank organised crime activities on separate variables such as the number of deaths directly caused by the activity. In principle, any variable could be compared amongst different organised crime activities, as long as they are measurable and a reasonable amount of reliable evidence is available (which may not always be the case). It only makes sense to compare, for example, the number of deaths of two (or more) organised crime activities if we have reliable death toll figures for both of them and if there is a reasonable degree of certitude that these murders/deaths were directly caused by the activity under scrutiny, e.g. large scale drug trafficking. A first source for finding such evidence would be official

\footnotetext{
${ }^{25}$ For pragmatic reasons discussed in section 'Assessing the reliability and validity of the definition of key concepts' we suggest that researchers use governmental definitions of organised crime.

${ }^{26}$ In a similar way we could, for example, try to assess the tastiness of desserts. We could come up with a list of attributes which we believe influence the tastiness of desserts, such as sweetness, colour, texture, or temperature, using different scoring ranges for each attribute and rank 'sweetness' higher than 'temperature'. We could provide reliable definitions of these attributes, so that other researchers could accurately repeat our research and come up with similar findings. However, what would we measure if we would use such a research method? Would we really have measured the tastiness of desserts? Would it be a valid way of measuring tastiness?
} 
statistics (e.g. police statistics). A second option would be to interview experts, such as police officers working for drug units or drug traffickers themselves. Such interviews should provide us with at least a rough idea of how violent organised crime drug markets are, but comparisons with other organised crime markets would be tricky, because such interviews probably will not provide us with very accurate estimates. A third source of evidence would be criminal case files and a fourth and final source would be open sources, such as the media and research reports. Combined, these sources could give us at least a rough image of a number of variables that could be interesting for policy makers, such as the use of violence within certain organised crime activities. We could probably even make tentative comparisons between different organised crime activities on separate variables without having to make normative judgments. Policymakers can then decide for themselves whether violence is worse than corruption or vice versa and rank the criminal activities accordingly.

\section{Conclusions}

That policymakers want to base the priorities they assign to law enforcement agencies on the basis of a transparent and scientific assessment is praiseworthy - and as such the OCTAs recently produced by governmental agencies and the methods developed by scholars and others cannot but be welcomed. Scientific rigour can improve such attempts by making sure at the very least that operational definitions of all key concepts are provided and that they are reliable and to the extent possible also valid.

In organised crime threat assessments and similar reports various things are investigated. Some of the studies focus on organised crime groups, others on activities, markets or phenomena. According to one OCTA, organised crime phenomena are more threatening when their consequences are more serious [20], according to another, organised crime groups pose a higher threat when they are more efficient and durable [7]. Some researchers state that one needs 28 attributes [22] to determine the threat of a crime group, others think 21 [36] or 19 [31] attributes are sufficient. Some researchers assert these attributes need scoring ranges in ranked order [31], others do not [22]. Who is right? Which agency or researcher is truly measuring the threats of organised crime? Or is it all just a matter of taste and can we interpret and define 'threat' and 'organised crime' in whatever way we like?

This cacophony is partially due to the ambiguous nature of the very concept of organised crime, a concept that has yet to find a definition on which an academic and/or political consensus could develop (see [14]). That explains why some studies reviewed here choose groups and other ones activities, markets or phenomena as the exemplary building block of organised crime. The ambiguity is further enhanced by the fact that the concepts of threat and risk are difficult to operationalise, because in essence these are normative concepts, like danger, tastiness or prettiness.

The ambiguity of these key concepts makes their operationalisation difficult. Therefore also, most governmental reports and scholarly methods reviewed here do not provide reliable and valid operational definitions in their attempts to assess the 
threats, risks or costs of organised crime. Four out of the nine governmental reports evaluated do not even provide a definition of their key concept $[6,13,26,34]$. Those that do $[5,7,20,28]$ mostly define their key concept(s) in such a way that it raises new questions. How to measure, for instance, the efficiency or durability [7] or intent and capability [5] of a criminal group? The governmental reports here evaluated provide insufficient information on these matters. Therefore, their analyses are not reproducible and hence not reliable. Similar defects can also be found in the attempts of a few scholars to develop threat or risk assessment methods. Klerks [22] and Albanese [1] do not provide a definition of their main concept and those that do $[24,36]$ provide insufficient explanation.

The RCMP [31] does not define threat, but does provide detailed information on the attribute list which is used to identify and rank-order threatening organised crime groups. Unlike Klerks, the RCMP explains the scoring ranges as well. However, no matter how detailed the instructions for assigning different scores on each attribute may be, the selection of the attributes themselves and their ranking are inevitably subjective and thus arbitrary decisions. Is a criminal group that corrupts officials worse than a criminal group using violence? According to Canadian law enforcement officers involved in the Sleipnir project it is ([31]: 3). How do they substantiate this conclusion? Well, it is their shared opinion on a list of attributes. Other groups in society might well develop different attribute lists. The fact that Vander Beken [36] and Klerks [22] come up with different lists and different scoring ranges is evidence of that.

We believe it would be more productive if researchers avoid vague wording such as threat and risk and use words and concepts on which there is a significant amount of consensus instead. Although the elaboration of their method could be improved Dubourg and Prichard (2007) step in the right direction by using monetary figures in their estimations. However, their methodology cannot be applied on the so-called imponderabilia. Therefore, their method should only be applied on the measurement of variables which can be expressed in monetary terms. For other variables, such as the use of violence within organised crime markets, we should use separate counting units (e.g. number of murders). By combining different sources we should be able to gain at least a rough picture of various variables within these activities, such as the use of violence. In that way we can make tentative comparisons amongst different organised crime activities on single variables, without having to make normative decisions.

\section{References}

1. Albanese, J. S. (2008). Risk assessment in organized crime: developing a market and product-based model to determine threat levels. Journal of Contemporary Criminal Justice, 24, 263-273.

2. Belgian Ministries of Internal Affairs and Justice. (2004). Executive Note Integrated Security (Kadernota Integrale Veiligheid) 2004. Available at www.just.fgov.be/nl_htm/parket/kadernota.pdf

3. Belgian Ministries of Internal Affairs and Justice. (2008). National Security Plan (Nationaal Veiligheidsplan) 2008-2011. Available at www.polfed-fedpol.be/pub/pdf/NVP2008-2011.pdf

4. Bryman, A. (2004). Social research methods (2nd ed.). New York: Oxford University Press.

5. Coleman, C., \& Moynihan, J. (1996). Understanding crime data: Haunted by the dark figure. Philadelphia: Open University Press. 
6. Crime and Misconduct Commission Queensland (CMCQ). (2004). Organised crime markets in Queensland: A strategic assessment. Available at http:/www.cmc.qld.gov.au/data/portal/00000005/ content/56473001141598820222.pdf

7. Criminal Intelligence Service Canada (CISC). (2008). Annual Report Organized Crime in Canada 2008. Available at http://www.cisc.gc.ca/annual_reports/annual_report_2008/document/report_ oc_2008_e.pdf

8. Dienst voor het Strafrechtelijk Beleid (DSB). (2008). Jaarrapport 2007 Georganiseerde Criminaliteit in België 2005-2006. (not available online)

9. Dubourg, R., \& Prichard, S. (2007). Organised Crime: revenues, economic and social costs, and criminal assets available for seizure. Available at http://www.cscs.ucl.ac.uk/club/e-library/organisedcrime/organised.pdf

10. van Duyne, P. C. (2007). OCTA 2006: the unfulfilled promise. Trends in Organized Crime, 3, 120-128.

11. van Duyne, P. C., \& Vander Beken, T. (2009). The incantations of the EU organised crime policy making. Crime, Law \& Social Change, 51(2), 261-281.

12. van Dijck, M. (2007). Discussing definitions of organised crime: word play in academic and political discourse. HUMSEC Journal, 1(1), 65-90.

13. Europol. (2006). EU Organised Crime Threat Assessment 2006. Available at http://www.europol. europa.eu/publications/European_Organised_Crime_Threat_Assessment_(OCTA)/OCTA2006.pdf

14. Europol. (2008). EU Organised Crime Threat Assessment 2008. Available at http://www.europol. europa.eu/publications/European_Organised_Crime_Threat_Assessment_(OCTA)/OCTA2008.pdf

15. Fijnaut, C., \& Paoli, L. (Eds.). (2004). Organised crime in Europe. Concepts, patterns and control policies in the European Union and Beyond. Dordrecht: Springer.

16. Finckenauer, J. O. (2005). Problems of definition: what is organized crime? Trends in Organized Crime, 8, 63-83.

17. Godfrey, C., Eaton, G., McDougall, C., \& Culyer, A. (2002). The Economic and Social Costs of Class A Drug Use in England and Wales, 2000. Home Office Research Study 249. Available at http://www. homeoffice.gov.uk/rds/pdfs2/hors249.pdf

18. Gordon, L., Tinsley, L., Godfrey, C., \& Parrot, S. (2006). The Economic and Social Costs of Class A Drug Use in England and Wales, 2003/04. In: Singleton, N., R. Murray \& L. Tinsley (2006) Measuring different aspects of problem drug use: methodological developments. Available at http:// www.homeoffice.gov.uk/rds/pdfs06/rdsolr1606.pdf

19. Hagan, F. E. (2006). "Organized Crime" and "organized crime": indeterminate problems of definition. Trends in Organized Crime, 9, 127-137.

20. Hobbs, D. (2000). Researching serious crime. In R. King \& E. Wincup (Eds.), Doing research on crime and justice (pp. 153-182). New York: Oxford University Press.

21. IPOL. (2008). Nationaal Dreigingsbeeld 2008 Georganiseerde Criminaliteit. Available at: http:// www.politie.nl/KLPD/Images/2008nationaaldreigingsbeeld_tcm35-423895.pdf

22. Kelly, R. J., Chin, K.-L., \& Schatzberg, R. (Eds.). (1994). Handbook of organized crime in the United States. Westport: Greenwood Press.

23. Klerks, P. (2000). Groot in de hasj: Theorie en praktijk van de georganiseerde criminaliteit. Alphen a/ d Rijn: Samsom.

24. Klerks, P. (2007). Methodological aspects of the Dutch National Threat Assessment. Trends in Organized Crime, 10, 91-101.

25. Kortekaas, J. (2005). Risicoanalyse georganiseerde misdaad. Uitwerking instrumentarium en toepassing op de ict-ontwikkelingen. Den Haag: Elsevier.

26. Mark, R. (1996). Research made simple. A handbook for social workers. London: Sage Publications.

27. Organised Crime Task Force (OCTF). (2007). Annual Report 2007 Serious and Organised Crime in Northern Ireland. Available at http://www.octf.gov.uk/uploads/publications/OCTF\%20Annual\%20Re port $\% 20$ and $\% 20$ Threat $\% 20$ Assessment $\% 202007$.pdf

28. Osborne, D., \& Wernicke, S. (2003). Introduction to crime analysis: Basic resources for criminal justice practice. New York: Haworth Press.

29. Queensland Crime Commission and Queensland Police Service (QCC). (1999). Project KRYSTAL: A Strategic Assessment of Organised Crime in Queensland. Milton. Available at http://www.cmc.qld. gov.au/data/portal/00000005/content/18651001141364539740.pdf

30. Reuter, P. (2009). The operation of the global drug market. In: Reuter, P., \& Trautmann, F. (Eds.) A report on global illicit drug markets 1998-2007. Trimbos and RAND. Available at: http://ec.europa. eu/justice_home/fsj/drugs/fsj_drugs_intro_en.htm

31. Royal Canadian Mounted Police (RCMP). (2000). The Long Matrix for Organised Crime. An Analytical Technique for Determining Relative Levels of Threat Posed by Organized Crime Groups. 
Abstract available at https://analysis.mitre.org/proceedings/Final_Papers_Files/135_Camera_Ready_ Paper.pdf

32. De Ruyver, B., Vander Beken, T., \& Black, C. (2000). Measuring organised crime in Belgium. A risk based methodology. Maklu: Antwerpen.

33. Sackman, H. (1974). Delphi Assessment: Expert Opinion, Forecasting, and Group Process. Santa Monica, CA: RAND. Available at http://www.rand.org/pubs/reports/2006/R1283.pdf

34. Serious Organised Crime Agency (SOCA). (2008). The United Kingdom Threat Assessment of Serious Organised Crime 2008/2009. Available at http:/www.soca.gov.uk/assessPublications/downloads/ UKTA2008-9NPM.pdf

35. UNODC. (2005). World Drug Report 2005. Available at: http://www.unodc.org/pdf/WDR_2005/ volume_1_web.pdf

36. Vander Beken, T. (2004). Risky business. Crime, Law and Social Change, 44, 471-516.

37. Vander Beken, T., \& Defruytier, M. (2004). Measure for measure. Methodological tools for assessing the risk of organised crime. In P. C. van Duyne, M. Jager, K. Von Lampe, \& J. L. Newell (Eds.), Threats and phantoms of organised crime, corruption and terrorism. Nijmegen: Wolf.

38. Woodiwiss, M. (2003). Transnational organised crime: The global reach of an American concept. In A. Edwards \& P. Gill (Eds.), Transnational organised crime: Perspectives on global security. London: Routledge. 